\title{
Manufacturing and Study of Mechanical Properties, Structure and Compatibility with Biological Objects of Plates and Wire from New Ti-25Nb-13Ta-5Zr Alloy
}

\author{
Sergey V. Gudkov ${ }^{1, *(D)}$, Alexander V. Simakin ${ }^{1}$, Mikhail A. Sevostyanov ${ }^{2,3}$, Sergey V. Konushkin ${ }^{2}$, \\ Monika Losertová ${ }^{4}\left(\mathbb{D}\right.$, Alexander Yu. Ivannikov ${ }^{2} \mathbb{C}$, Alexey G. Kolmakov ${ }^{2}$ \\ and Andrey Yu. Izmailov ${ }^{5}$ \\ 1 Biophotonics Centre, Prokhorov General Physics Institute of the Russian Academy of Sciences, \\ 119991 Moscow, Russia; avsimakin@gmail.com \\ 2 Laboratory of Physical and Chemical Foundations of Metallurgy of Non-Ferrous and Rare Metals, \\ A.A. Baikov Institute of Metallurgy and Materials Science of the Russian Academy of Sciences, \\ 119334 Moscow, Russia; cmakp@mail.ru (M.A.S.); venev.55@mail.ru (S.V.K.); imet-lab25@yandex.ru (A.Y.I.); \\ kolmakov@imet.ac.ru (A.G.K.) \\ 3 Department of Biologically Active Substances, All-Russian Research Institute of Phytopatology, \\ Bol'shie Vyazemy, 143050 Moscow, Russia \\ 4 Faculty of Metallurgy and Materials Engineering, VŠB-Technical University of Ostrava, 70800 Poruba, \\ Czech Republic; mlosertova@vsb.cz \\ 5 Technological Transport Department, Federal State Budgetary Scientific Institution “Federal Scientific \\ Agroengineering Center VIM" (FSAC VIM), 109428 Moscow, Russia; vim@vim.ru \\ * Correspondence: S_makariy@rambler.ru
}

Received: 29 October 2020; Accepted: 20 November 2020; Published: 26 November 2020

\begin{abstract}
A Ti-25Nb-13Ta-5Zr alloy was produced and studied in this work, and plates and wires were made from this alloy. It is shown that the Ti- $25 \mathrm{Nb}-13 \mathrm{Ta}-5 \mathrm{Zr}$ alloy has the required mechanical properties and a $\beta$-crystal phase. Microstructures were present on the surface of the alloy with a height of several hundred nm, located at a distance of $1.5-2 \mu \mathrm{m}$ from each other. Ti- $25 \mathrm{Nb}-13 \mathrm{Ta}-5 \mathrm{Zr}$ was superior to nitinol in terms of the formation of long-living reactive protein species and the generation of reactive oxygen species. Cell cultivation on $\mathrm{Ti}-25 \mathrm{Nb}-13 \mathrm{Ta}-5 \mathrm{Zr}$ alloy surfaces revealed a significant mitotic index $(2 \%)$ and a small number of nonviable cells $(<5 \%)$. The cells were actively attached and spread over the alloy. The biocompatibility of $\mathrm{Ti}-25 \mathrm{Nb}-13 \mathrm{Ta}-5 \mathrm{Zr}$ was verified by experiments on the implantation of the alloy in the form of plates and coiled wires. The surface morphology of the specimens after biological trials was not significantly altered. The experimental data we obtained suggest that $\mathrm{Ti}-25 \mathrm{Nb}-13 \mathrm{Ta}-5 \mathrm{Zr}$ is suitable for potential applications in biology and medicine.
\end{abstract}

Keywords: $\mathrm{Ti}-\mathrm{Nb}-\mathrm{Ta}-\mathrm{Zr}$ alloys; biocompatibility; mechanical characteristics; structural characteristics

\section{Introduction}

In 1891, Gluck performed the first joint replacement [1]. Since then, the search and production of novel materials for prosthesis fabrication have continued. Materials for prostheses must have the required mechanical properties, such as chemical resistance, biocompatibility and processability. Titanium was one of the first metals to comply with all these requirements [2]. When compared to medical stainless steel, titanium has better biocompatibility and a relatively low elastic modulus [3]. The requirements of the properties of the materials for implantation became increasingly stricter with time. Although many continued to consider titanium a "reference" metal, its use became limited due to the local corrosion of titanium [4], its insufficient mechanical characteristics for a number 
of applications [5] and the progression of possible metal losses [6]. The development of medicine increased the requirements for implanted materials and led to the production of materials with unique properties [7]. Titanium was thus replaced by its alloys. Nitinol became one of the most widely used titanium alloys [8]. It is a nickel-titanium alloy with all the advantages of titanium, and, in addition, has hyperelastic and shape-memory properties [9]. However, nitinol contains nickel ( $\mathrm{Ni} 56 \mathrm{wt} . \%$; $\mathrm{Ti} \sim 44 \mathrm{wt} . \%$ ), and the release of nickel ions from the implant can cause local and systemic allergic reactions in patients [10]. To solve allergy-related problems, attempts are being made to substitute nickel with other metals. For example, the Ti-Al alloy showed excellent mechanical properties and resistance to oxidation [11]. Ti-Al-based alloys (Ti-Al-V, Ti-Al-Si, Ti-Al-Zr-Mo-V) also demonstrated excellent properties [12-14], but for a long time, these alloys have caused allergic reactions and toxic effects [15]. Ti-Zr-Fe-Cr [16], Ti-Sn-Nb-Cr [17], Ti-25Nb-3Zr-3Mo-2Sn [18] and Ti-Fe-Ta [19] are outstanding alloys, albeit with a potential problem. All these alloys contain metals of variable-valence metals, such as $\mathrm{Fe}, \mathrm{Cr}, \mathrm{Mo}, \mathrm{Mn}, \mathrm{Cu}, \mathrm{Ni}$ and so forth. Variable-valence metals are capable of catalyzing the hydrogen peroxide decomposition reaction to form a dangerous hydroxyl radical. Over time, alloys appeared that did not contain transition metals. The most successful examples of such alloys are $\mathrm{Ti}-, \mathrm{Ta}-, \mathrm{Nb}$ - and $\mathrm{Zr}$-based alloys. The first alloy consisting of these elements used in medicine was Ti-15Zr-4Nb-4Ta [20]. The authors reported that the alloy has significant resistance to corrosion caused by biological fluids. It was later shown that other alloys of this type also have high corrosion resistance [21-24]. The corrosion resistance of a small number of alloys based on these metals was tested by the authors of [25]. One of the most corrosion-resistant alloys was $\mathrm{Ti}-25 \mathrm{Nb}-13 \mathrm{Ta}-5 \mathrm{Zr}$.

In addition to the corrosion resistance of the alloy, its mechanical properties are particularly important for biological applications. A significant difference in the mechanical properties of alloys and bone tissue is the main disadvantage of metal implants. Metal implants have a higher Young's modulus in comparison to bone tissue [26]. The difference in mechanical properties under prolonged cyclic loading leads to the loss of the mechanical connection between the implant and bone tissue. $\mathrm{Ti}-\mathrm{Nb}-\mathrm{Ta}-\mathrm{Zr}$ alloys are appropriate for implant manufacturing as the Young's modulus ranges from 35 to 55 GPa [23-28]. The niobium content [29] and production technology have the greatest impact on the Young's modulus value in such alloys.

Biocompatibility is a crucial property of a medical implant. It is known that $\mathrm{Ti}, \mathrm{Nb}, \mathrm{Ta}$ and $\mathrm{Zr}$ are the most biocompatible chemical elements used for manufacturing metallic biomaterials. It is assumed that these metals can cause minimal negative side effects in mammals. The biocompatibility of $\mathrm{Ti}-, \mathrm{Nb}-$, $\mathrm{Zr}$ - and Ta-based alloys was first shown at the beginning of the 2000s for Ti-29Nb-13Ta-4.6Zr [30]. It has now been established that the vast majority of $\mathrm{Ti}-, \mathrm{Zr}-, \mathrm{Nb}$ - and Ta-based alloys have excellent biocompatibility [31]. The biocompatibility of alloys depends on both the chemical composition and surface structure [31]. Many different physical and chemical methods of surface structuring are currently being developed. These methods may be different in nature and lead to different results. Some methods are universal; for example, with the help of laser treatment, one can apply both ordered and disordered structures of different sizes to the surface [32]. The same applies to other physical high-energy surface treatment technologies [33]. The surface structures can be both micro- [34] and nanoscale [35]. Surface structuring almost always involves the consumption of additional energy and resources. Therefore, it is most beneficial to obtain structured surfaces during material production.

This manuscript describes the processes of manufacturing a Ti- $25 \mathrm{Nb}-13 \mathrm{Ta}-5 \mathrm{Zr}$ alloy and obtaining plates and wires from it. When the wire was manufactured, micro- and nanoscale structures are formed on its surface. The biocompatibility of plates and wires made of $\mathrm{Ti}-25 \mathrm{Nb}-13 \mathrm{Ta}-5 \mathrm{Zr}$ was higher than the biocompatibility of products made of nitinol obtained using the same technology. Products made of Ti-25Nb-13Ta-5Zr did not cause short-term toxic effects either on individual cells or the entire body of laboratory rodents. This alloy has been found to have remarkable mechanical properties. It can be argued that $\mathrm{Ti}-25 \mathrm{Nb}-13 \mathrm{Ta}-5 \mathrm{Zr}$ is a promising alloy for use in veterinary medicine and medicine. 


\section{Materials and Methods}

\subsection{Manufacturing of the Ti-25Nb-13Ta-5Zr Alloy}

Smelting was performed in an electric arc furnace (DCP, Moscow, Russia) with the help of a nonmelting tungsten electrode. Samples were placed in a copper water-cooled crystallizer. The furnace working chamber was first vacuumized to the pressure of $1.3 \mathrm{~Pa}$ and then filled with argon gas. Before smelting, the zirconia getter was melted. For even distribution of $\mathrm{Ti}, \mathrm{Nb}$, $\mathrm{Ta}$ and $\mathrm{Zr}$ in the alloy, each ingot was remelted at least 5 times. Each time the ingot was melted, the thief turned over its longitudinal axis by 180 degrees. The duration of smelting of one ingot was $1.5 \mathrm{~min}$. To homogenize the alloy and eliminate the dendritic structure on its surface, a homogenizing annealing process was carried out $\left(12 \mathrm{~h}\right.$, temperature $800^{\circ} \mathrm{C}$, pressure $\left.0.25 \mathrm{~Pa}\right)$.

\subsection{Preparation of $\mathrm{Ti}-25 \mathrm{Nb}-13 \mathrm{Ta}-5 \mathrm{Zr}$ Alloy Plates and Wire}

The following technology was used to produce $1 \mathrm{~mm}$ thick plates. Primary deformation of ingots (thickness $1.0-1.2 \mathrm{~cm}$ ) was carried out by means of hot rolling $\left(600{ }^{\circ} \mathrm{C}\right)$ on the two-roller mill DUO-300 (NPO ETS, Moscow, Russia) (draft per pass 0.5-1.5 mm). For experiments with cell cultures, $1 \mathrm{~cm} \times 1 \mathrm{~cm} \times 0.1 \mathrm{~cm}$ plates were produced. Implants for animals were manufactured in $0.5 \mathrm{~cm} \times 1 \mathrm{~cm}$ $\times 0.1 \mathrm{~cm}$ sizes. With the help of polishing, visual defects in the products were eliminated.

To produce wire, the smelted ingots were deformed at $600{ }^{\circ} \mathrm{C}$ in grooves of a rolling mill to $10 \mathrm{~mm}$ $\times 10 \mathrm{~mm}$ cross sections. Rotational swaging of the slabs was performed on radial swagers (ENIMS, Leningrad, USSR) with sequential replacement of the dies to the diameter of $2 \mathrm{~mm}$. Double drawing of the wire was performed from $2 \mathrm{~mm}$ to $280 \mu \mathrm{m}$ diameter; both wire and dies were heated to $150{ }^{\circ} \mathrm{C}$. Drawing rate was from 2 to $6 \mathrm{~m} / \mathrm{min}$ and die diameter step was $100 \mu \mathrm{m}$. After obtaining the $280 \mu \mathrm{m}$ wire, it was polished to elimination of apparent flaws. The produced item was annealed in a vacuum (residual pressure of 0.0002 ) for $20 \mathrm{~min}$ at $800{ }^{\circ} \mathrm{C}$.

Initially, the wire was polished with felt discs moistened with DiaMaxx Poly water-based diamond suspension (particle size 6, 3 or $1 \mu \mathrm{m}$ ). For each type of suspension, there were 50 grinding cycles with wire pulling speed of $0.3 \mathrm{~m} / \mathrm{s}$ and disc rotation speed of $2000 \mathrm{rpm}$. After mechanical polishing, ultrasonic cleaning of the wire was carried out for $30 \mathrm{~min}$ to remove residual grease and abrasive material. After that, the wire was electrochemically polished (etched) in a solution of hydrofluoric and sulfuric acids with deionized water $\left(\mathrm{HF}: 3 \mathrm{H}_{2} \mathrm{SO}_{4}: 16 \mathrm{H}_{2} \mathrm{O}\right)$ (Reachem, Moscow, Russia) for $30 \mathrm{~s}$.

\subsection{Study of Physicochemical and Mechanical Properties of the Alloy}

The mechanical characteristics of the alloy were investigated with the experimental stand Instron 3382 (Instron corp., Norwood, MA, USA). The tests included determination of all main mechanical characteristics [24]. Layer-by-layer elemental analysis was carried out, as well as surface morphology, using the Vega II EMS (Tescan, Brno, Czech Republic) and the JAMP 9500F Auger Spectrometer (JEOL, Tokyo, Japan). The differential scanning calorimeter Netzsch STA-409PC (Netzsch, Selb, Germany) was used in calorimetric study. The high-temperature dilatometer Netzsch DIL 402 C7G (Netzsch, Selb, Germany) was used in dilatometry. Light microscopy was performed with a GX51 (Olympus, Düsseldorf, Germany). Surface topology was investigated with the help of a Nanopics 2000 (Seiko, Tokyo, Japan) atomic force microscope and a MIM 321 (Amphora Lab, Moscow, Russia) laser modulation interference microscope. X-ray diffractograms were carried out on an ARL X'TRA (Thermo Fisher Scientific, Waltham, MA, USA).

\subsection{Detection of Long-Lived Reactive Protein Species (LRPS)}

For this, $100 \mathrm{~mm}$ wires made from the alloy $\mathrm{Ti}-25 \mathrm{Nb}-13 \mathrm{Ta}-5 \mathrm{Zr}$ were placed in a water solution of Bovine Serum Albumin (BSA) with concentration of $100 \mathrm{mg} / \mathrm{L}$. The protein solution was incubated with the wire for $2 \mathrm{~h}$ at $37^{\circ} \mathrm{C}$. After that, all the samples were incubated in the dark at room temperature $\left(20^{\circ} \mathrm{C}\right)$ for $30 \mathrm{~min}$. Determination of LRPS was carried out using the method of intrinsic 
chemiluminescence of protein solutions [36,37] with the specially designed chemiluminometer Biotoks 7AM (NPO ECE, Moscow, Russia) [38].

\subsection{Detection of Reactive Oxygen Species (ROS)}

A $100 \mathrm{~mm}$ wire of $\mathrm{Ti}-25 \mathrm{Nb}-13 \mathrm{Ta}-5 \mathrm{Zr}$ alloy was placed into a Petri dish with deionized water. Water and wire were exposed for $2 \mathrm{~h}$ in the dark at $37^{\circ} \mathrm{C}$. The enhanced chemiluminescence method (horseradish luminol-4-iodophenol peroxidase system) was used to quantify hydrogen peroxide in aqueous solutions [39]. The chemiluminometer Biotoks 7AM (NPO ECE, Moscow, Russia) was used for luminescence measurements. The sensitivity of the method allowed determination of $\mathrm{H}_{2} \mathrm{O}_{2}$ at minimal concentrations of $0.1 \mathrm{nM}$ [40].

For quantitative determination of hydroxyl radical concentration, a fluorescent marker, cumarin-3-carboxylic acid (CCA) (Sigma-Aldrich, St. Louis, Mo, USA), was used. After hydroxylation, CCA is converted into 7-hydroxycumarin-3-carboxylic acid, which has intense fluorescence. Wire from the Ti-30Nb-10Ta- $5 \mathrm{Zr}$ alloy was immersed into a water solution of CCA and placed for $2 \mathrm{~h}$ in a temperature of $80^{\circ} \mathrm{C}$. Intensity of 7-OH-CCA fluorescence was measured on an AVS spectrofluorimeter (GPI RAS, Moscow, Russia) at $\lambda_{\mathrm{ex}}=407 \mathrm{~nm}, \lambda_{\mathrm{em}}=470 \mathrm{~nm}$. The sensitivity of the method allowed determination of $\mathrm{OH}$ radicals at minimal concentrations of $<0.5 \mathrm{nM}$ [41].

\subsection{Cell Culture}

The eucaryotic cell line SH-SY5Y was used in cell culture experiments. The cells were incubated with fluorescent markers (MitoTracker Deep Red FM, Propidium Iodide, Hoechst 33342). After that, the cells were washed from the dyes in Hank's solution for $10 \mathrm{~min}$. Hoechst 33342 stains the nuclei of both dead and living cells. Propidium iodide stains only cells with perforated membranes (dead cells). MitoTracker Deep Red FM stains only mitochondria. Cells were investigated using a DMI6000 (Leica, Germany). The stained nuclei were counted in the ImageJ program with the Cell Counter plugin. The details of cell culture manipulations were described previously [42].

\subsection{Experimental Animals}

All implantation experiments were conducted on Wistar male rats. The animals were kept in vivarium conditions (standard temperature, humidity, $12 \mathrm{~h}$ day, $12 \mathrm{~h}$ night). All operations with animals were in accordance with the national standards of the Russian Federation and approved by the Bioethics Committee of the Biofotonics Centre of GPI RAS.

\subsection{Implantation Model}

To study the degree of biocompatibility of the Ti-25Nb-13Ta- $5 \mathrm{Zr}$ alloy, a model of subcutaneous implantation was used [43]. Three plates or wires were implanted subcutaneously into each rat through an incision in lower dorsal region. The operation was undertaken under anesthesia. Animals were withdrawn from the experiment 14 or 60 days after implantation. The implant with surrounding tissue was cut out and fixed in a neutral formaldehyde solution (4\%). The tissue incisions were dyed with Gill hematoxylin-eosin.

\section{Results}

\subsection{Characteristics of the Ti-25Nb-13Ta-5Zr Alloy}

Analysis of the $\mathrm{Ti}-25 \mathrm{Nb}-13 \mathrm{Ta}-5 \mathrm{Zr}$ alloy surface of plates was performed layer by layer. It was determined that the elemental composition of the alloy was comparatively constant at a depth of more than $250 \mu \mathrm{m}$ from the surface: $\mathrm{Ti}-57 \%, \mathrm{Nb}-25 \%, \mathrm{Ta}-13 \%, \mathrm{Zr}-5 \%$ (Figure $1 \mathrm{~A}$ ). It was shown that $\mathrm{Zr}$ content was constant, both at the surface and inside of the plates. The content of Ti atoms on the surface was significantly lower than that inside the plate (about 20\%). Contrariwise, the content of Ta on the surface exceeded the content of tantalum inside the plates. Also, the surface contained a 
substantial proportion of oxides ( $50 \%)$. The oxygen content was about $10 \%$ at a depth of $100 \mathrm{~nm}$ from the plate surface. At a depth of $250 \mathrm{~nm}$, there was no oxygen. At distances of more than $300 \mathrm{~nm}$ from the surface, oxygen atoms were not detected.
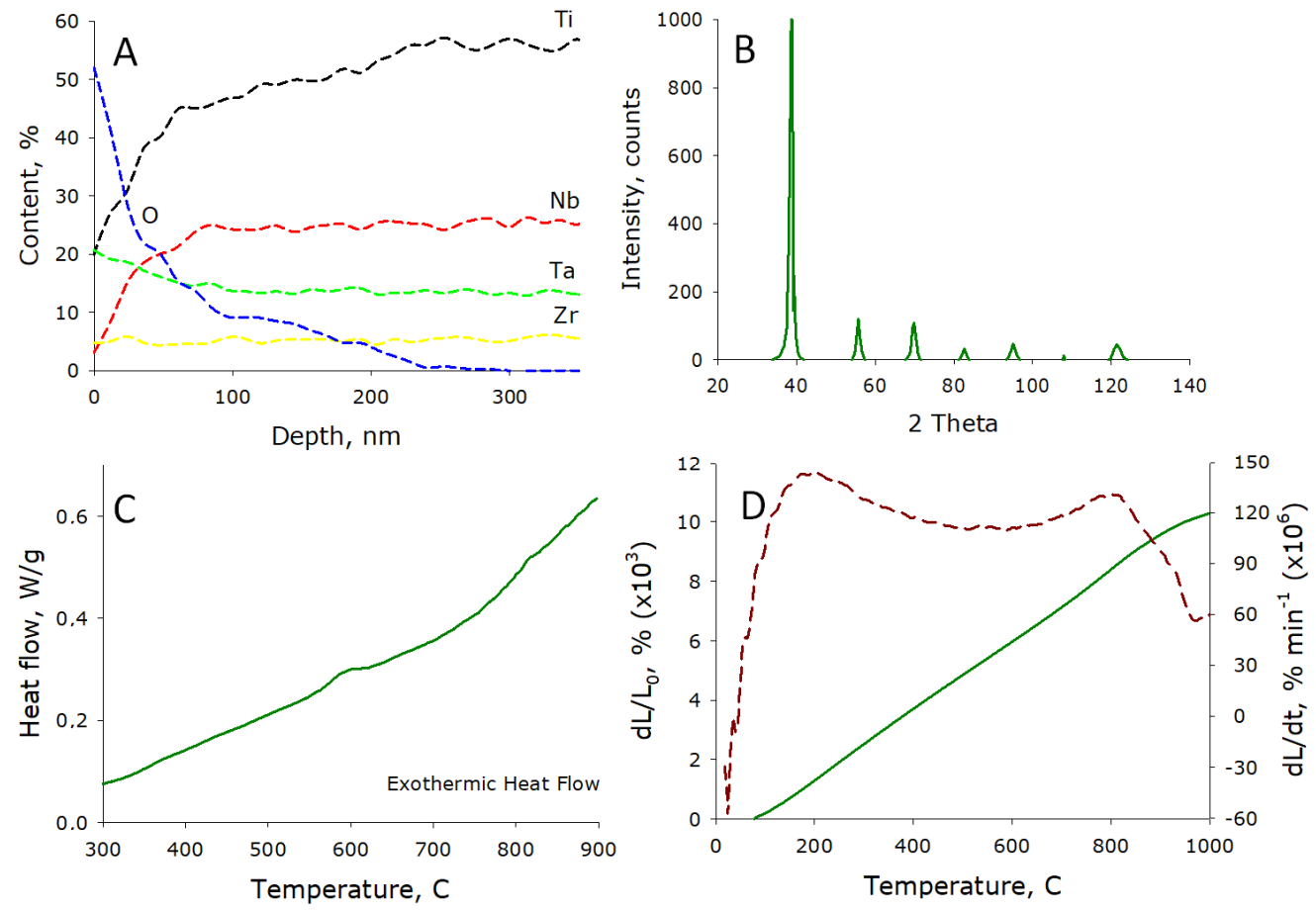

Figure 1. Properties of the Ti-25Nb-13Ta-5Zr alloy. (A) Layer-by-layer analysis of the surface of Ti-25Nb-13Ta-5Zr. (B) Results of X-ray phase analysis of Ti-25Nb-13Ta-5Zr. (C) Heat measurement function of the Ti-25Nb-13Ta-5Zr alloy. (D) Dilatometric analysis of the Ti-25Nb-13Ta-5Zr alloy.

A study of the phase composition of the Ti-25Nb-13Ta-5Zr alloy was conducted (Figure 1B). The alloy was shown to be polycrystallic and monophasic with the $\beta$-Ti type of crystal lattice (cubic syngony). The crystal lattice parameter was $3.30606 \pm 0.00006 \AA$. Peak positions: $38.6534(011$, beta); 55.7120 (0 0 2, beta); 69.7522 (1 1 2, beta); 82.5874 (0 22 beta); 95.0417 (0 1 3, beta); 107.7345 (2 2 2, beta); 121.4087 ( 123 , beta). The peak with the position 107.7345 has a small intensity $(0.2 \%)$ compared to the overall level and is hardly visible on the plot. It was shown that $\mathrm{Ti}-25 \mathrm{Nb}-13 \mathrm{Ta}-5 \mathrm{Zr}$ alloy samples are polycrystalline. The mechanical tests of the alloy carried out showed that the yield strength of the Ti-25Nb-13Ta-5Zr alloy was $617 \mathrm{MPa}$. The tensile strength of the alloy was shown to be around $736 \mathrm{MPa}$. The Young's modulus, however, had a value of around $47.81 \mathrm{GPa}$. Ti-25Nb-13Ta-5Zr alloy relative elongation was found to be about $2.3 \%$. Calorimetric survey data is presented in Figure 1C. The study of the specimens was performed at $300-900{ }^{\circ} \mathrm{C}$ in an argon atmosphere. The first phase transition was seen at a temperature a little lower than $600^{\circ} \mathrm{C}$, whereas the second phase transition was at $850^{\circ} \mathrm{C}$. The dilatometric study data is presented in Figure 1D. The linear thermal expansion of the sample as a function of temperature was studied. Thermal expansion is a measure of dimensional changes of an object with temperature. Areas of softening and/or thermal expansion of the products can be seen on the curve. Anomaly temperatures are present. They correspond to thermal processes associated with changes in the properties of products.

Microstructure of the alloy following smelting (Figure 2A), homogenizing annealing (Figure 2B) was studied. The wire drawn from the Ti-30Nb-10Ta-5Zr alloy had a more complicated surface topology (Figure 2C), and after polishing (Figure 2D), it had fewer surface flaws. Most of the surface had no obvious microscopic defects. Such relatively smooth (according to optical microscopy) surface areas were studied with the help of interference and atomic force microscopy. Relatively even sites had longitudinal ridgelike structures and folds (Figure 3A) up to $500 \mathrm{~nm}$ in height. The analysis 
of topology on a nanoscale level revealed the presence of minor irregularities (up to 100-150 nm in height), even between the ridgelike structures or on their tops (Figure 3B). Ordered relief on the surface was not observed.

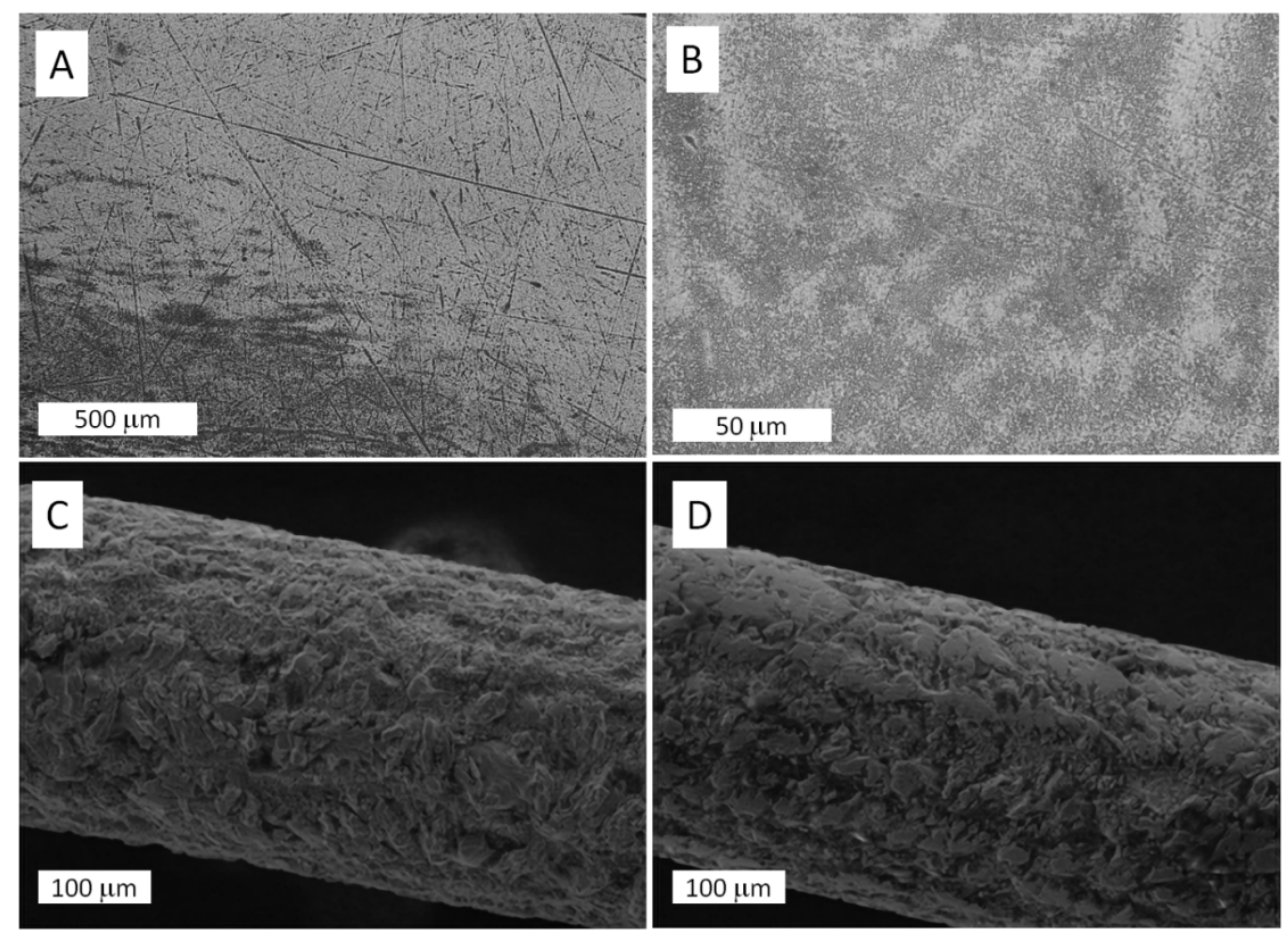

Figure 2. Microphotographs of the surface of the Ti-25Nb-13Ta-5Zr alloy. (A) Optical microphotograph of the surface of the alloy after smelting. (B) Optical microphotograph of the surface of the alloy after polishing. (C) SEM photograph of the surface of a Ti-25Nb-13Ta-5Zr alloy wire after formation. (D) SEM photograph of the surface of a Ti-25Nb-13Ta-5Zr alloy wire after polishing.
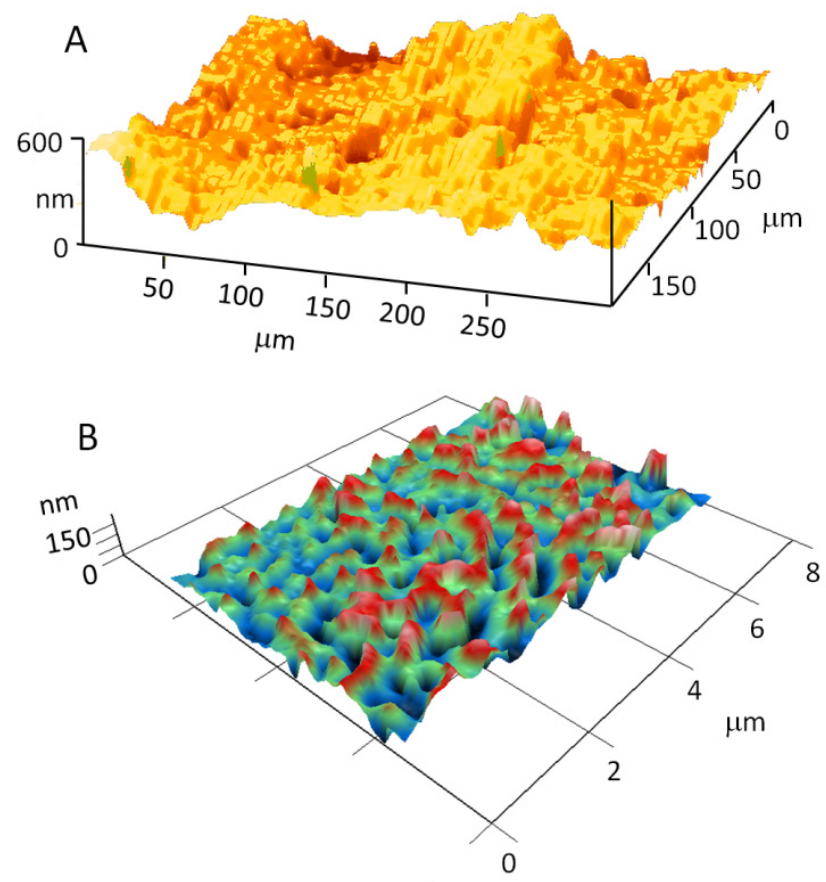

Figure 3. Topology of the Ti-25Nb-13Ta-5Zr alloy surface. (A) Analysis of surface topology using an atomic force microscope. (B) Analysis of surface topology study using a laser modulation interference microscope. 


\subsection{Influence of the Ti-25Nb-13Ta-5Zr Alloy on Biological Macromolecules}

The influence of the Ti-25Nb-13Ta-5Zr alloy on the formation of LRPS was investigated (Figure 4A). It is known that in the presence of some metals, there is a more intense development of redox reactions, and as the temperature rises, these processes are even more active. In this regard, the experiments were conducted at temperature values exceeding room temperature. Pure titanium served for positive comparisons (control). Nitinol was used for negative comparisons. The LRPS were shown to be evolved in our system. The rate of its formation did not change significantly in the presence of titanium. Nitinol caused around a $60 \%$ increase in the formation of LRPS. Addition of the alloy we have manufactured led to an increase in LRPS production of only $30 \%$.

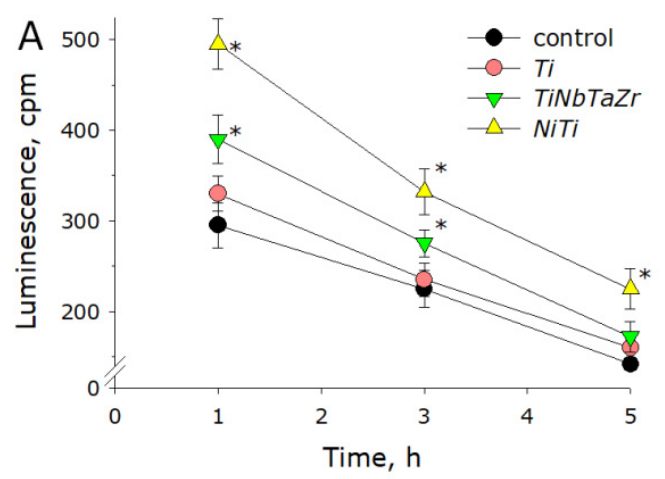

C

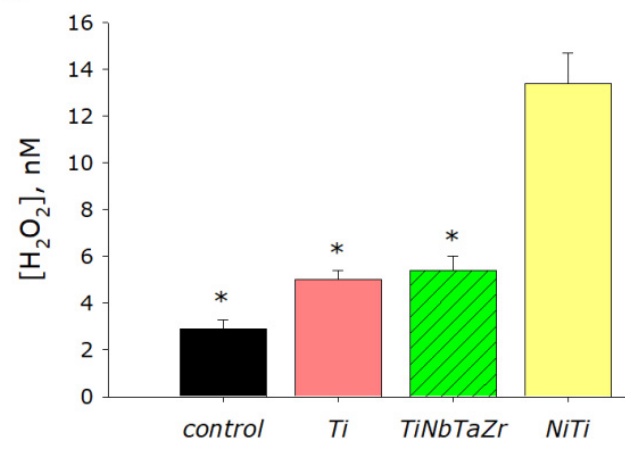

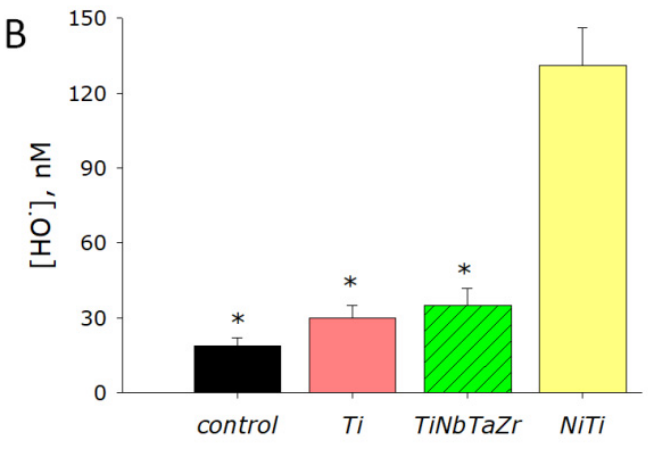

D

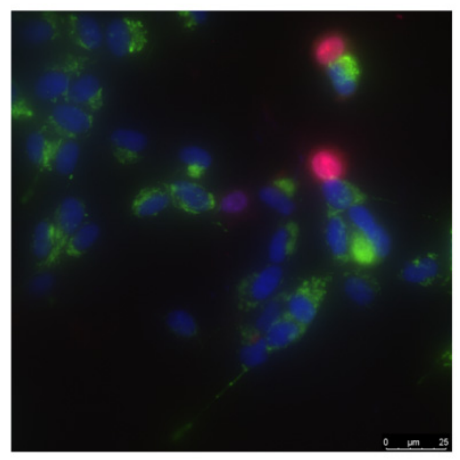

Figure 4. Effect of the $\mathrm{Ti}-25 \mathrm{Nb}-13 \mathrm{Ta}-5 \mathrm{Zr}$ alloy (TiNbTaZr) on the generation of long-lived reactive protein species and reactive oxygen species, compared to Ti, nitinol (NiTi) and a control. (A) Effect of $\mathrm{Ti}-25 \mathrm{Nb}-13 \mathrm{Ta}-5 \mathrm{Zr}$ on the formation of long-lived reactive protein species $\left(2 \mathrm{~h}, 40{ }^{\circ} \mathrm{C}\right)$. (B) Effect of $\mathrm{Ti}-25 \mathrm{Nb}-13 \mathrm{Ta}-5 \mathrm{Zr}$ on the generation of hydroxyl radicals $\left(2 \mathrm{~h}, 80^{\circ} \mathrm{C}\right)$. (C) Effect of Ti-25Nb-13Ta-5Zr on the formation of hydrogen peroxide $\left(2 \mathrm{~h}, 40^{\circ} \mathrm{C}\right)$. (D) Microphotograph of a cell culture, obtained by an overlay of three fluorescent channels and transmitted light. Cytoplasm is colored green; cell nuclei are colored red in the state of apoptosis. Asterisks indicate a significant difference at the $5 \%$ level (Student's unpaired $t$-test) in comparison with the control $(p<0.05)$.

Reactive oxygen species such as $\mathrm{OH}$ radicals and hydrogen peroxide $\left(\mathrm{H}_{2} \mathrm{O}_{2}\right)$ were shown to be evolved in the studied system (Figure 4B,C). Addition of nitinol to the system increased hydrogen peroxide generation rate by almost six-fold. Meanwhile, addition of titanium did not increase $\mathrm{H}_{2} \mathrm{O}_{2}$ generation rate by more than a half, whereas $\mathrm{Ti}-25 \mathrm{Nb}-13 \mathrm{Ta}-5 \mathrm{Zr}$ caused a two-fold increase. Hydroxyl radical concentration became almost 10 times higher in the presence of nitinol. The Ti- $30 \mathrm{Nb}-10 \mathrm{Ta}-5 \mathrm{Zr}$ alloy and titanium increased the rate of hydroxyl radical generation by $70 \%$ and $40 \%$, respectively.

A comprehensive cell culture micrograph is presented below (Figure 5D). The micrograph was obtained by overlaying three images obtained in different fluorescence channels. Besides fluorescence channels, the image was also simultaneously recorded in transmitted light. The nuclei of all the cells are 
colored blue on the micrograph (Hoechst 33342). Two cells have pink color of nuclei (propidium iodide), indicating these cells have damaged plasma membranes, thus being nonviable.
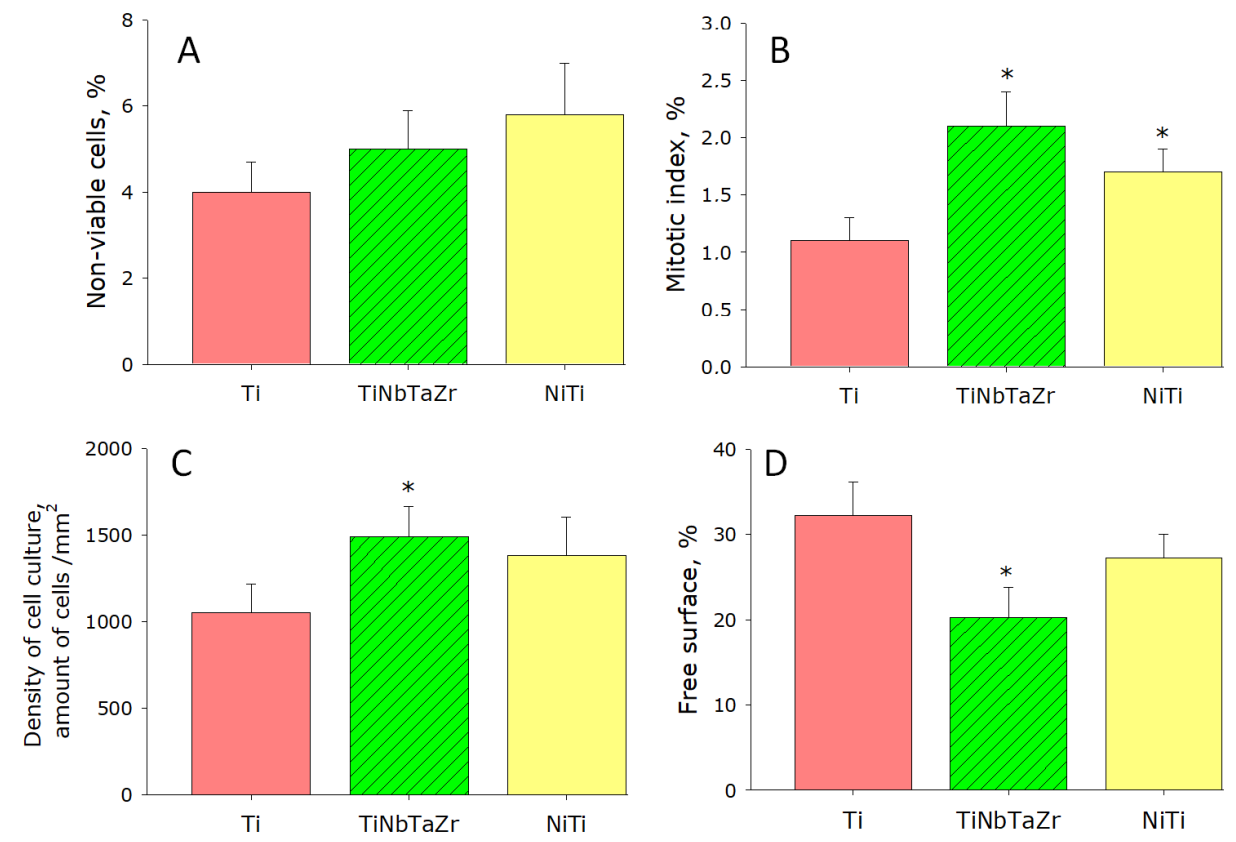

Figure 5. Effect of the Ti-25Nb-13Ta-5Zr alloy on the main characteristics of cell culture growth and development. (A) Effect of Ti-25Nb-13Ta-5Zr on cell viability. (B) Effect of Ti-25Nb-13Ta-5Zr on the mitotic index of a cell population. (C) Effect of Ti-25Nb-10Ta-13Zr on cell culture density. (D) Effect of $\mathrm{Ti}-25 \mathrm{Nb}-13 \mathrm{Ta}-5 \mathrm{Zr}$ on the rate of spreading. Asterisks indicate a significant difference at the $5 \%$ level (Student's unpaired $t$-test) in comparison with the control $(p<0.05)$.

\subsection{Influence of the Ti-25Nb-13Ta-5Zr Alloy on Cell Cultures}

Influence of the Ti-25Nb-13Ta-5Zr alloy, nitinol and titanium on the viability of cell was studied (Figure 5A). When eukaryotic cells were grown on titanium, the number of nonviable cells did not exceed $4 \%$. When eukaryotic cells were grown on the alloy we have manufactured, about $5 \%$ of the cells became nonviable. When nitinol was used as a substrate, the number of nonviable cells increased almost 1.5-fold (6\%) compared to the control. The mitotic indexes (MIs) of cells were calculated to evaluate the cells' mitotic activity (Figure 5B). The MI determined for the SH-SY5Y cell culture grown on titanium plates was $1.2 \%$. When using nitinol as a substrate, the MI comprised $1.7 \%$. The MI of cultured SH-SY5Y cells on the Ti- $25 \mathrm{Nb}-13 \mathrm{Ta}-5 \mathrm{Zr}$ substrate was about $2.0 \%$. This shows that the MI of cells cultivated on the $\mathrm{Ti}-25 \mathrm{Nb}-13 \mathrm{Ta}-5 \mathrm{Zr}$ substrate was $75 \%$ higher than that of titanium and $20 \%$ higher than that of nitinol. Besides fission capacity and viability, the impact of the materials examined on cell culture densities was investigated. It was established that cells growing on the Ti surface had an average cell culture density of $10^{3}$ cells $/ \mathrm{mm}^{2}$ (Figure 5C). Cells growing on the NiTi substrate had a culture density of almost $1.4 \times 10^{3}$ cells $/ \mathrm{mm}^{2}$. More than $1.4 \times 10^{3}$ cells $/ \mathrm{mm}^{2}$ could be observed on the Ti-25Nb-13Ta-5Zr alloy. After $72 \mathrm{~h}$ of continuous cultivation, the percentage of colonized surfaces of the materials examined was assessed. It was found that on the surface of Ti-25Nb-13Ta-5Zr, cells are more efficiently attached compared to on Ti (Figure 5D). In other words, cells growing for $72 \mathrm{~h}$ on the surface of titanium colonized a smaller surface area than cells growing on Ti-25Nb-13Ta-5Zr. It should be noted that on all surfaces, the cells did not form a continuous monolayer after $72 \mathrm{~h}$ of cultivation: only individual elements. On titanium samples, cells took up approximately $70 \%$ of the surface; for nitinol, this was $75 \%$; and for Ti- $25 \mathrm{Nb}-13 \mathrm{Ta}-5 \mathrm{Zr}, 80 \%$. 


\subsection{Influence of the Ti-25Nb-13Ta-5Zr Alloy on Animal Tissue during Implantation}

Biocompatibility studies of plates and wires of the Ti-30Nb-10Ta-5Zr alloy were conducted in vivo with the help of subcutaneous implantation. When implanting the plates of $10 \mathrm{~mm} \times 5 \mathrm{~mm} \times 1 \mathrm{~mm}$ in size, they were chamfered in order to avoid tissue damage by sharp edges. When implanting the wire, it was looped to prevent the rupture of surrounding tissue with sharp ends. The conditions of operation on animals were normal during the postoperative period. Fourteen days after the operation, no inflammation or tissues necrosis was observed in the animals (Figure 6A). Similar results were obtained with the implantation of Ti (Figure 6C) and NiTi (Figure 6D) plates: there were no signs of inflammation or tissue necrosis. Nickel plates were used as a positive control (Figure 6E). On the micrograph of the preparations, one can see fibrous tissue, foci of inflammation and fibers with a disturbed structure. Sixty days after surgery, a connective tissue capsule was formed around the implants in animals (Figure 6B, bracket). Capsule formation is standard for metallic biocompatible materials.

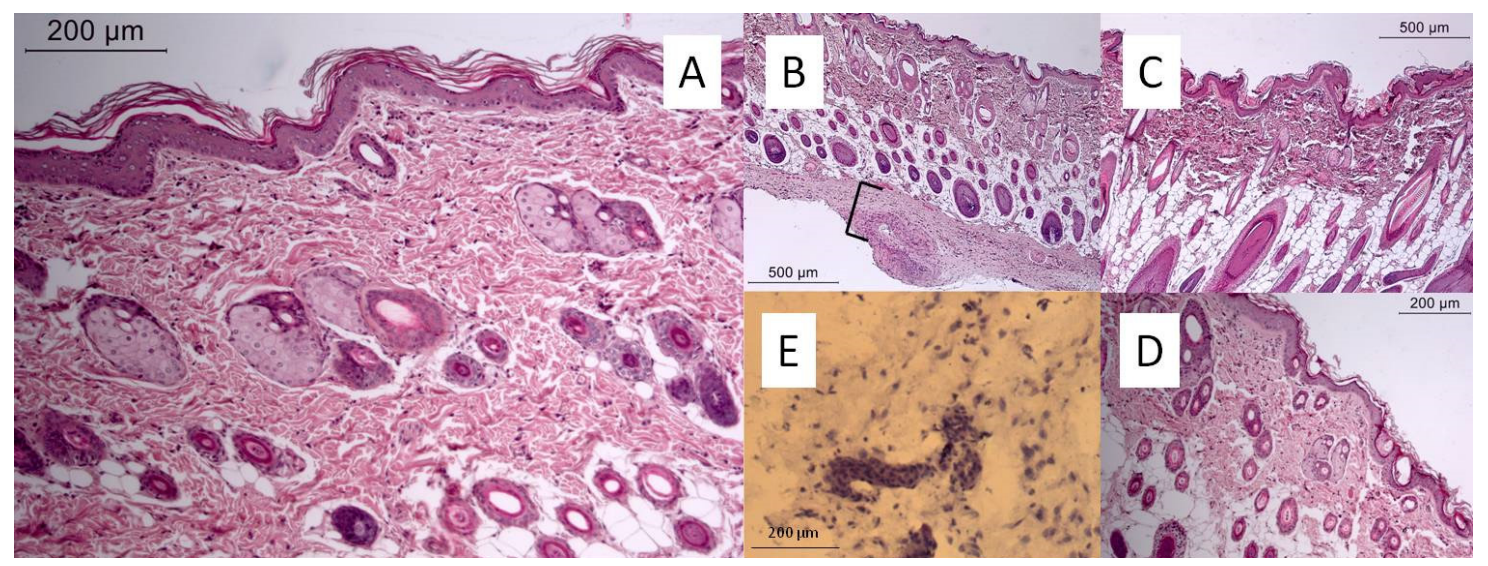

Figure 6. Microphotographs of tissue slices surrounding implants derived from the (A) Ti-25Nb-13Ta-5Zr alloy (bar size $200 \mu \mathrm{m}, 14$ days after surgery), (B) Ti-25Nb-13Ta-5Zr alloy (bar size $500 \mu \mathrm{m}, 60$ days after surgery; the bracket denotes the connective tissue capsule), (C) Ti (bar size $500 \mu \mathrm{m}, 14$ days after surgery), (D) NiTi (bar size $500 \mu \mathrm{m}, 14$ days after surgery) and (E) Ni (bar size $500 \mu \mathrm{m}, 14$ days after surgery).

After these biological trials, surfaces of the $\mathrm{Ti}-30 \mathrm{Nb}-10 \mathrm{Ta}-5 \mathrm{Zr}$ plates were investigated. The control samples were stored in a dry place at a temperature of $20-22{ }^{\circ} \mathrm{C}$. Some of the plates were in contact with bovine blood serum circulating in a closed loop for 60 days. Test specimens were in contact with cells and the culture environment for 60 days. Another part of the samples was tested after implantation by the animals within 60 days. Surfaces of the Ti-30Nb-10Ta-5Zr plates essentially did not change after biological trials.

\section{Discussion}

Titanium possesses perfect biocompatibility, but its wide use in medicine is limited by its low mechanical strength [44]. In medicine and veterinary medicine, alloys based on titanium are an obvious alternative to pure Ti. Often, alloys based on titanium have essential mechanical strength, which could be an issue in the production of alloys with small Young's modulus that mimic natural bone tissue [45]. This study determined for the first time certain physicochemical and mechanical features of the new Ti-25Nb-13Ta-5Zr alloy. Alloy biocompatibility was investigated in vitro and in vivo. It was established that the prospective $\mathrm{Ti}-25 \mathrm{Nb}-13 \mathrm{Ta}-5 \mathrm{Zr}$ alloy has good cytocompatibility and biocompatibility and does not cause inflammatory reactions.

It was demonstrated that the new $\mathrm{Ti}-25 \mathrm{Nb}-13 \mathrm{Ta}-5 \mathrm{Zr}$ alloy has a homogeneous composition (Figure 1A). The surface layers of the alloy are poor in titanium and niobium content and also contain 
significant amounts of oxides. Probably, the surface layers contain only titanium or niobium oxides. Earlier, when studying the physicochemical properties of a Ti-29Nb-13Ta-4.6Zr alloy, it was shown that surface oxidation was associated mainly with the formation of titanium oxides [46]. Modeling of surface oxidation processes predicts that the formation of titanium and niobium oxides can significantly affect the surface topology and a number of other properties [47]. The effect of oxygen on the physicochemical properties of alloys based on $\mathrm{Ti}-\mathrm{Nb}-\mathrm{Ta}-\mathrm{Zr}$ was studied earlier [48]. It is known that niobium is a metal that gives the alloys the properties of a $\beta$-phase. Niobium has already been applied to the production of titanium alloys with a $\beta$-phase and small Young's modulus [49]. It was testified that the Ti-25Nb-13Ta-5Zr alloy has a pure $\beta$-phase, which indicates that all elements in the alloy are effective $\beta$-phase stabilizing elements (Figure 1B). Calorimetric and dilatometric (Figure 1C,D) properties of $\mathrm{Ti}-25 \mathrm{Nb}-13 \mathrm{Ta}-5 \mathrm{Zr}$ were similar to those of other TiNbTaZr alloys [50]. It was established that surface morphology significantly affects the growth and development of cells. At the nanoscale level, the $25 \mathrm{Nb}-13 \mathrm{Ta}-5 \mathrm{Zr}$ alloy surface contains folds up to $500 \mathrm{~nm}$ high, longitudinal ridge-like structures and protrusions several hundred nanometers high (Figure 3). It is likely that the presence of nanostructures can significantly contribute to the biocompatibility of the alloy. Overall, the chemical, physical and mechanical characteristics of the Ti-25Nb-13Ta-5Zr alloy suggest that it has potential for use in veterinary and biomedical applications.

The idea of replacing titanium with titanium alloys arose several decades ago. One of the first titanium alloys to be widely used in medicine was nitinol (NiTi) [51]. The wide application of nitinol is linked with its exclusive characteristics, namely superelasticity and shape-memory effect. Significant toxicity of nickel has become the cost for these properties [52]. Nickel, like other metals of variable valency, is an active participant of reducing and oxidizing reactions that lead to ROS generation in biological tissue and liquid [53]. An increase in ROS concentration over the capacity of antioxidant systems of cells leads to the development of oxidative stress [54]. Oxidative stress is always associated with hazardous events, based on mass oxidative damage of biomolecules [55]. We have demonstrated (Figure 4C,D) that intensive ROS formation occurs in the presence of nitinol in aqueous solutions. For convenience of comparison, we summarized all the values we measured in the form of a Table 1 . With the Ti-25Nb-13Ta-5Zr alloy, ROS formation was much slower than with nitinol. Transitional metals can take part not only in ROS generation, but other processes [56]. It has been shown that metals from the variable-valence group may cause LRPS to form [39]. It has previously been shown that LRPS can damage the structure of biological macromolecules, leading to the mutation and malignization of cells [57]. It has been established (Figure 3A) that in the presence of nitinol, the LRPS generation rate increases by $60 \%$. When the Ti-25Nb-13Ta-5Zr alloy was used, ROS formation was much slower than with nitinol. This makes it possible to compensate for about than half of the malicious effects of NiTi on biomolecules. These conclusions were proved by the experiments on cell cultures. When working with the cell cultures, Ti, NiTi and Ti-25Nb-13Ta-5Zr alloys were applied. It was shown that the $\mathrm{Ti}-25 \mathrm{Nb}-13 \mathrm{Ta}-5 \mathrm{Zr}$ alloy surface was preferable for attachment of the cells (Figure 5). Thus, the Ti-25Nb-13Ta-5Zr alloy surfaces were the most biocompatible of all the investigated surface samples.

Table 1. Influence of Ti, TiNbTaZr and NiTi plates on the rates of generation of reactive oxygen species and cell growth/development.

\begin{tabular}{cccccccc}
\hline Materials & $\begin{array}{c}\text { LRPS, } \\
\text { cpm }\end{array}$ & $\begin{array}{c}{\left[\mathbf{H}_{\mathbf{2}} \mathbf{O}_{\mathbf{2}}\right],} \\
\mathbf{n M}\end{array}$ & $\begin{array}{c}{[\bullet \mathbf{O H}],} \\
\mathbf{n M}\end{array}$ & $\begin{array}{c}\text { Nonviable } \\
\text { Cells, \% }\end{array}$ & MI, \% & $\begin{array}{c}\text { Density of Cells, } \\
\text { cells/mm } \mathbf{2}\end{array}$ & $\begin{array}{c}\text { Free } \\
\text { Surface, } \%\end{array}$ \\
\hline $\mathrm{Ti}$ & $330 \pm 19$ & $5.0 \pm 0.4$ & $30 \pm 5$ & $4.0 \pm 0.7$ & $1.1 \pm 0.2$ & $1050 \pm 165$ & $32.2 \pm 4.0$ \\
$\mathrm{TiNbTaZr}$ & $390 \pm 27$ & $5.4 \pm 0.6$ & $35 \pm 7$ & $5.0 \pm 0.9$ & $2.1 \pm 0.3$ & $1490 \pm 175$ & $20.3 \pm 3.5$ \\
$\mathrm{NiTi}$ & $495 \pm 28$ & $13.4 \pm 1.3$ & $131 \pm 15$ & $5.8 \pm 1.2$ & $1.7 \pm 0.2$ & $1380 \pm 225$ & $27.3 \pm 2.7$ \\
\hline \multicolumn{7}{c}{ LRPS: long-lived reactive protein species. }
\end{tabular}

Thus, the technology of manufacturing the Ti-25Nb-13Ta-5Zr alloy and products from it (wire and plates) has been developed. It has been established that the alloy we obtained has 
the necessary mechanical properties. The surface of the alloy and wire plates has nano- and microreliefs. The Ti-25Nb-13Ta-5Zr alloy has been found to be able to generate less ROS and LRPS than the NiTi alloy. When the Ti-25Nb-13Ta-5Zr alloy was used to grow cell cultures, cells had a higher mitotic index and surface colonization rate compared to Ti or NiTi. The results obtained from the implantation of the alloy also confirm the conclusion that the Ti-25Nb-13Ta-5Zr is highly biocompatible. The surface morphology of the samples did not change during biological tests. The Ti-25Nb-13Ta-5Zr alloy is considered to be a material potentially suitable for use in veterinary medicine and biomedicine.

Author Contributions: Methodology, A.V.S.; formal analysis, M.L.; conceptualization, M.A.S. and S.V.G.; software, S.V.K.; investigation, M.A.S., S.V.K., A.V.S. and A.Y.I. (Alexander Yu. Ivannikov); resources, A.Y.I. (Andrey Yu. Izmailov); writing, S.V.G.; visualization, A.Y.I. (Alexander Yu. Ivannikov); supervision, A.G.K.; funding acquisition, A.Y.I. (Andrey Yu. Izmailov). All authors have read and agreed to the published version of the manuscript.

Funding: This work was supported by the grant of the Ministry of Science and Higher Education of the Russian Federation for large scientific projects in priority areas of scientific and technological development (075-15-2020-774).

Acknowledgments: The microscopy was performed using the equipment of the Collective Use Centre of GPI RAS. We are grateful to Natalya V. Khunderyakova for providing the micrograph for Figure 6E.

Conflicts of Interest: The authors declare no conflict of interest.

\section{References}

1. Gluck, T. Report on the Positive Results Obtained by the Modern Surgical Experiment Regarding the Suture and Replacement of Defects of Superior Tissue, as well as the Utilization of Re-absorbable and Living Tamponade in Surgery. Clin. Orthop. Relat. Res. 2011, 469, 1528-1535. [CrossRef] [PubMed]

2. Condon, R.E.; Beder, O.E. A study of titanium implants in a corrosion-producing environment. Surgery 1964, 55, 714-717. [PubMed]

3. Leventhal, G.S. Titanium, a metal for surgery. J. Bone Jt. Surg. 1951, 33, 473-474. [CrossRef]

4. Hirakawa, K. Letter to the editor on "Titanium neck-titanium stem corrosion in a modular neck stem". Arthroplast. Today 2020, 6, 129. [CrossRef]

5. Kaur, M.; Singh, K. Review on titanium and titanium based alloys as biomaterials for orthopaedic applications. Mater. Sci. Eng. C 2019, 102, 844-862. [CrossRef]

6. Khan, W.S.; Agarwal, M.; Malik, A.A.; Cox, A.G.; Denton, J.; Holt, E.M. Chromium, cobalt and titanium metallosis involving a Nottingham shoulder replacement. J. Bone Jt. Surg. Br. 2008, 90, 502-505. [CrossRef]

7. Gibson, T. Biomechanics in plastic surgery. In Biomechanics and Related Bio-Engineering Topics; Elsevier: Amsterdam, The Netherlands, 1965; pp. 129-134.

8. Civjan, S.; Huget, E.F.; DeSimon, L.B. Potential applications of certain nickel-titanium (nitinol) alloys. J. Dent. Res. 1975, 54, 89-96. [CrossRef]

9. Sherif, M.M.; Ozbulut, O.E. Tensile and superelastic fatigue characterization of NiTi shape memory cables. Smart Mater. Struct. 2018, 27, 015007. [CrossRef]

10. Ort, M.J.; Geissler, S.; Rakow, A.; Schoon, J. The Allergic Bone Marrow? The Immuno-Capacity of the Human Bone Marrow in Context of Metal-Associated Hypersensitivity Reactions. Front. Immunol. 2019, 10, 2232. [CrossRef]

11. Shimojo, N.; Kondo, C.; Yamashita, K.; Hoshino, T.; Hayakawa, T. Cytotoxicity analysis of a novel titanium alloy in vitro: Adhesion, spreading, and proliferation of human gingival fibroblasts. Biomed Mater. Eng. 2007, 17, 127-135.

12. Karolewska, K.; Ligaj, B.; Wirwicki, M.; Szala, G. Strength analysis of Ti6Al4V titanium alloy produced by the use of additive manufacturing method under static load conditions. J. Mater. Res. Tech. 2019, 8, 1365-1379. [CrossRef]

13. Hao, F.; Xiao, J.; Feng, Y.; Wang, Y.; Ju, J. Tensile deformation behavior of a near- $\alpha$ titanium alloy Ti-6Al-2Zr-1Mo-1V under a wide temperature range. J. Mater. Res. Tech. 2020, 9, 2818-2831. [CrossRef]

14. Lee, J.; Park, H.; Kim, J.; Jang, J.; Hong, S.; Oh, I. Constitutive behavior and microstructural evolution in Ti-Al-Si ternary alloys processed by mechanical milling and spark plasma sintering. J. Mater. Res. Tech. 2020, 9, 2247-2258. [CrossRef] 
15. Biesiekierski, A.; Wang, J.; Gepreel, M.A.N.; Wen, C. A New Look at Biomedical Ti-Based Shape Memory Alloys. Acta Biomater. 2012, 8, 1661-1669. [CrossRef] [PubMed]

16. Rabadia, C.D.; Liu, Y.J.; Wang, L.; Sun, H.; Zhang, L.C. Laves phase precipitation in Ti-Zr-Fe-Cr alloys with high strength and large plasticity. Mater. Des. 2018, 154, 228-238. [CrossRef]

17. Jawed, S.F.; Rabadia, C.D.; Liu, Y.J.; Wang, L.Q.; Li, Y.H.; Zhang, X.H.; Zhang, L.C. Mechanical characterization and deformation behavior of $\beta$-stabilized Ti-Nb-Sn-Cr alloys. J. Alloy. Compd. 2019, 792, 684-693. [CrossRef]

18. Dargusch, M.S.; Wang, G.; Kent, D.; Bermingham, M.; Venezuela, J.; Frith, J.E.; Yu, Z.; Yu, S.; Shi, Z. Comparison of the Microstructure and Biocorrosion Properties of Additively Manufactured and Conventionally Fabricated near $\beta$ Ti-25Nb-3Zr-3Mo-2Sn Alloy. ACS Biomater. Sci. Eng. 2019, 5, 5844-5856. [CrossRef]

19. Kuroda, D.; Kawasaki, H.; Yamamoto, A.; Hiromoto, S.; Hanawa, T. Mechanical properties and microstructures of new Ti-Fe-Ta and Ti-Fe-Ta-Zr system alloys. Mater. Sci. Eng. C 2005, 25, 312-320. [CrossRef]

20. Okazaki, Y.; Rao, S.; Ito, Y.; Tateishi, T. Corrosion resistance, mechanical properties, corrosion fatigue strength and cytocompatibility of new Ti alloys without Al and V. Biomaterials 1998, 19, 1197-1215. [CrossRef]

21. Okazaki, Y.; Gotoh, E. Comparison of metal release from various metallic biomaterials in vitro. Biomaterials 2005, 26, 11-21. [CrossRef]

22. Ban, S. Effect of alkaline treatment of pure titanium and its alloys on the bonding strength of dental veneering resins. J. Biomed Mater. Res. 2003, 66, 138-145. [CrossRef] [PubMed]

23. Sevostyanov, M.A.; Kolmakov, A.G.; Sergiyenko, K.V.; Kaplan, M.A.; Baikin, A.S.; Gudkov, S.V. Mechanical, physical-chemical and biological properties of the new Ti-30Nb-13Ta-5Zr alloy. J. Mater. Sci. 2020, 55, 14516-14529. [CrossRef]

24. Konushkin, S.V.; Sergiyenko, K.V.; Nasakina, E.O.; Leontyev, V.G.; Kuznetsova, O.G.; Titov, D.D.; Tsareva, A.M.; Dormidontov, N.A.; Kirsankin, A.A.; Kannykin, S.V.; et al. Study of the physicochemical and biological properties of the new promising Ti-20Nb-13Ta-5Zr alloy for biomedical applications. Mater. Chem. Phys. 2020, 255, 123557. [CrossRef]

25. Sevostyanov, M.A.; Losertova, M.; Nasakina, E.O. Corrosive researches of nonnickel shape memory alloy. IOP Conf. Ser. Mater. Sci. Eng. 2019, 525, 012068. [CrossRef]

26. Sailer, I.; Philipp, A.; Zembic, A. A systematic review of the performance of ceramic and metal implant abutments supporting fixed implant reconstructions. Clin. Oral Implants Res. 2009, 20, 4-31. [CrossRef]

27. Wei, Q.; Wang, L.; Fu, Y. Influence of oxygen content on microstructure and mechanical properties of Ti-Nb-Ta-Zr alloy. Mater. Des. 2011, 32, 2934-2939. [CrossRef]

28. Li, B.Q.; Xie, R.Z.; Lu, X. Microstructure, mechanical property and corrosion behavior of porous Ti-Ta-Nb-Zr. Bioact. Mater. 2020, 5, 564-568. [CrossRef]

29. Chen, J.; Ma, F.; Liu, P. Effects of $\mathrm{Nb}$ on superelasticity and low modulus properties of metastable $\beta$-type Ti-Nb-Ta-Zr biomedical alloys. J. Mater. Eng. Perform 2019, 28, 1410-1418. [CrossRef]

30. Niinomi, M. Fatigue performance and cyto-toxicity of low rigidity titanium alloy, Ti-29Nb-13Ta-4.6Zr. Biomaterials 2003, 24, 2673-2683. [CrossRef]

31. Zhang, L.C.; Chen, L.Y. A Review on Biomedical Titanium Alloys: Recent Progress and Prospect. Adv. Eng. Mater. 2019, 21, 1801215. [CrossRef]

32. Kusoglu, I.M.; Gökce, B.; Barcikowski, S. Research trends in laser powder bed fusion of Al alloys within the last decade. Addit. Manuf. 2020, 36, 101489. [CrossRef]

33. Barkhudarov, E.M.; Kossyi, I.A.; Anpilov, A.M.; Ivashkin, P.I.; Artem'ev, K.V.; Moryakov, I.V.; Misakyan, M.A.; Christofi, N.; Burmistrov, D.E.; Smirnova, V.V.; et al. New Nanostructured Carbon Coating Inhibits Bacterial Growth, but Does Not Influence on Animal Cells. Nanomaterials 2020, 10, 2130. [CrossRef] [PubMed]

34. Dolgaev, S.I.; Lavrishev, S.V.; Lyalin, A.A.; Simakin, A.V.; Voronov, V.V.; Shafeev, G.A. Formation of conical microstructures upon laser evaporation of solids. Appl. Phys. A 2001, 73, 177-181. [CrossRef]

35. Barmina, E.V.; Stratakis, E.; Barberoglou, M.; Stolyarov, V.N.; Stolyarov, I.N.; Fotakis, C.; Shafeev, G.A. Laser-assisted nanostructuring of Tungsten in liquid environment. Appl. Surf. Sci. 2012, 258, 5898-5902. [CrossRef]

36. Gudkov, S.V.; Guryev, E.L.; Gapeyev, A.B.; Sharapov, M.G.; Bunkin, N.F.; Shkirin, A.V.; Zabelina, T.S.; Glinushkin, A.P.; Sevost'yanov, M.A.; Belosludtsev, K.N.; et al. Unmodified hydrated C60 fullerene molecules exhibit antioxidant properties, prevent damage to DNA and proteins induced by reactive oxygen species and protect mice against injuries caused by radiation-induced oxidative stress. Nanomed. Nanotechnol. Biol. Med. 2019, 15, 37-46. [CrossRef] [PubMed] 
37. Sharapov, M.G.; Novoselov, V.I.; Fesenko, E.E.; Bruskov, V.I.; Gudkov, S.V. The role of peroxiredoxin 6 in neutralization of X-ray mediated oxidative stress: Effects on gene expression, preservation of radiosensitive tissues and postradiation survival of animals. Free Radic. Res. 2017, 51, 148-166. [CrossRef] [PubMed]

38. Ivanov, V.E.; Usacheva, A.M.; Chernikov, A.V.; Bruskov, V.I.; Gudkov, S.V. Formation of long-lived reactive species of blood serum proteins induced by low-intensity irradiation of helium-neon laser and their involvement in the generation of reactive oxygen species. J. Photochem. Photobiol. B 2017, 176, 36-43. [CrossRef]

39. Gudkov, S.V.; Penkov, N.V.; Baimler, I.V.; Lyakhov, G.A.; Pustovoy, V.I.; Simakin, A.V.; Sarimov, R.M.; Scherbakov, I.A. Effect of Mechanical Shaking on the Physicochemical Properties of Aqueous Solutions. Int. J. Mol. Sci. 2020, 21, 8033. [CrossRef]

40. Simakin, A.V.; Astashev, M.E.; Baimler, I.V.; Uvarov, O.V.; Voronov, V.V.; Vedunova, M.V.; Sevost'yanov, M.A.; Belosludtsev, K.N.; Gudkov, S.V. The Effect of Gold Nanoparticles Concentration and Laser Fluence on the Laser-Induced Water Decomposition. J. Phys. Chem. B 2019, 123, 1869-1880. [CrossRef]

41. Sevostyanov, M.A.; Baikin, A.S.; Sergienko, K.V.; Shatova, L.A.; Kirsankin, A.A.; Baymler, I.V.; Shkirin, A.V.; Gudkov, S.V. Biodegradable stent coatings on the basis of PLGA polymers of different molecular mass, sustaining a steady release of the thrombolityc enzyme streptokinase. React. Funct. Polym. 2020, 150, 104550. [CrossRef]

42. Kaplan, M.A.; Sergienko, K.V.; Kolmakova, A.A.; Konushkin, S.V.; Baikin, A.S.; Kolmakov, A.G.; Sevostyanov, M.A.; Kulikov, A.V.; Ivanov, V.E.; Belosludtsev, K.N.; et al. Development of a biocompatible plga polymers with a thrombolytic effect for stents coatings. J. Biomater. Sci. Polym. Ed. 2020, 31, 1405-1420. [CrossRef] [PubMed]

43. Williams, D.F. Titanium as a metal for implantation. Part 1: Physical properties. J. Med. Eng. Technol. 1977, 1, 195-198. [CrossRef] [PubMed]

44. Lemons, J.E.; Niemann, K.M.; Weiss, A.B. Biocompatibility studies on surgical-grade titanium-, cobalt-, and iron-base alloys. J. Biomed. Mater. Res. 1976, 10, 549-553. [CrossRef] [PubMed]

45. Abdel-Hady, M.; Hinoshita, K.; Morinaga, M. General approach to phase stability and elastic properties of $\beta$-type Ti-alloys using electronic parameters. Scr. Mater. 2006, 55, 477-480. [CrossRef]

46. Homma, T.; Arafah, A.; Haley, D.; Nakai, M.; Niinomi, M.; Moody, M.P. Effect of alloying elements on microstructural evolution in oxygen content controlled $\mathrm{Ti}-29 \mathrm{Nb}-13 \mathrm{Ta}-4.6 \mathrm{Zr}$ (wt $\%$ ) alloys for biomedical applications during aging. Mater. Sci. Eng. A 2018, 709, 312-321. [CrossRef]

47. Ishiguro, Y.; Tsukada, Y.; Koyama, T. Phase-field study of the spinodal decomposition rate of $\beta$ phase in oxygen-added Ti-Nb alloys. Comput. Mater. Sci. 2020, 174, 109471. [CrossRef]

48. Nagasako, N.; Asahi, R.; Isheim, D.; Seidman, D.N.; Kuramoto, S.; Furuta, T. Microscopic study of gum-metal alloys: A role of trace oxygen for dislocation-free deformation. Acta Mater. 2016, 105, 347-354. [CrossRef]

49. Sergienko, K.V.; Titov, D.D.; Konushkin, S.V.; Baikin, A.S.; Nasakina, E.O.; Baskakova, M.I.; Bespamiatnova, A. Study of the coefficient of heat expansion of TiNbTaZr alloy. IOP Conf. Ser. Mater. Sci. Eng. 2019, 525, 012092. [CrossRef]

50. Levashov, E.A.; Petrzhik, M.I.; Shtansky, D.V.; Kiryukhantsev-Korneev, P.V.; Sheveyko, A.N.; Valiev, R.Z.; Gunderov, D.V.; Prokoshkin, S.D.; Korotitskiy, A.V.; Smolin, A.Y. Nanostructured titanium alloys and multicomponent bioactive films: Mechanical behavior at indentation. Mater. Sci. Eng. A 2013, 570, 51-62. [CrossRef]

51. Cutright, D.E.; Bhaskar, S.N.; Perez, B.; Johnson, R.M.; Cowan, G.S., Jr. Tissue reaction to nitinol wire alloy. Oral Surg. Oral Med. Oral Pathol. Oral Radiol. 1973, 35, 578-584. [CrossRef]

52. Rajan, G.P.; Eikelboom, R.H.; Anandacoomaraswamy, K.S.; Atlas, M.D. In vivo performance of the Nitinol shape-memory stapes prosthesis during hearing restoration surgery in otosclerosis: A first report. J. Biomed. Mater. Res. Part B 2005, 72, 305-309. [CrossRef] [PubMed]

53. Huang, X.; Zhuang, Z.; Frenkel, K.; Klein, C.B.; Costa, M. The role of nickel and nickel-mediated reactive oxygen species in the mechanism of nickel carcinogenesis. Environ. Health Perspect. 1994, 102, 281-284. [PubMed]

54. Sharapov, M.G.; Novoselov, V.I.; Gudkov, S.V. Radioprotective Role of Peroxiredoxin 6. Antioxidants 2019, 8, 15. [CrossRef] [PubMed] 
55. Filev, A.D.; Shmarina, G.V.; Ershova, E.S.; Veiko, N.N.; Martynov, A.V.; Borzikova, M.A.; Poletkina, A.A.; Dolgikh, O.A.; Veiko, V.P.; Bekker, A.A.; et al. Oxidized Cell-Free DNA Role in the Antioxidant Defense Mechanisms under Stress. Oxidative Med. Cell. Longev. 2019, 2019, 1245749. [CrossRef] [PubMed]

56. Gudkov, S.V.; Chernikov, A.V.; Bruskov, V.I. Chemical and radiological toxicity of uranium compounds. Russ. J. Gen. Chem. 2016, 86, 1531-1538. [CrossRef]

57. Kumagai, J.; Masui, K.; Itagaki, Y.; Shiotani, M.; Kodama, S.; Watanabe, M.; Miyazaki, T. Long-lived mutagenic radicals induced in mammalian cells by ionizing radiation are mainly localized to proteins. Radiat. Res. 2003, 160, 95-102. [CrossRef]

Publisher's Note: MDPI stays neutral with regard to jurisdictional claims in published maps and institutional affiliations.

(C) 2020 by the authors. Licensee MDPI, Basel, Switzerland. This article is an open access article distributed under the terms and conditions of the Creative Commons Attribution (CC BY) license (http://creativecommons.org/licenses/by/4.0/). 